\title{
Morphological Characteristics and Soil Mechanical Properties of a Gully in the Dry-Hot Valley Region of Southwestern China
}

\author{
Su Zhang ${ }^{1,2}$, Donghong Xiong1*, Yong Yuan ${ }^{1,2}$, Han Wu ${ }^{1,2}$, Wanxin $\mathrm{Li}^{1,2}$, \\ Lin Liu ${ }^{1,2}$, Zhengan Su${ }^{1}$ \\ 'Key Laboratory of Mountain Hazards and Earth Surface Processes, Institute of Mountain \\ Hazards and the Environment, Chinese Academy of Sciences, Chengdu, Sichuan, China \\ ${ }^{2}$ University of the Chinese Academy of Sciences, Beijing, China
}

Received: 13 July 2018

Accepted: 18 October 2018

\begin{abstract}
Gully erosion is a dominant process causing severe soil loss and soil degradation in the Dry-Hot Valley region of southwestern China. Little attention has been paid to the spatiotemporal variations of the morphological characteristics of gullies. The aims of the present study were to explore gully morphological characteristics and its soil mechanical properties. In our study, we identify the main types of gullies according to their activity and the characteristics of their impact factors in the study area. Results showed that 1) three different active gully types could be classified: active, semi-active and stable; 2) the morphological characteristics of different active gullies were significantly different; 3) the soil shear strength under different parts of gullies varies with different active degrees of gullies; and 4) the gully head-cut height, gully wall-slope and its bed-gradient ratio were the most important indicators for reflecting gully morphology, which was affected by soil mechanical properties in it. It is the premise and foundation of further study on gully erosion to carry out the study of a gully's morphological characteristics. These findings improve the understanding of a gully's morphological characteristics and its soil mechanical properties in the Dry-Hot Valley region.
\end{abstract}

Keywords: morphological characteristics, mechanical properties, gully, Dry-Hot Valley region

\section{Introduction}

Gully erosion was one of the serious environmental problems in the Yuanmou Dry-Hot Valley downstream of the Jinsha River [1-5], where soil erosion intensity

*e-mail: dhxiong@imde.ac.cn reached up to $1.64 \times 104 \mathrm{t} /\left(\mathrm{km}^{2} \bullet \mathrm{a}\right)$ and gully density was up to $3.0 \sim 5.0 \mathrm{~km} / \mathrm{km}^{2}$, with a maximum of $7.4 \mathrm{~km} / \mathrm{km}^{2}$ [3-5]. At present, there was a great deal of research focusing on one of the parts among gully head, gully wall and gully bed in the region [3-6], while the comparative studies on various parts of gullies are seldom reported. The soil shear strength was one of the measuring indicators for studying soil stability [7-10], which could characterize the stability 
of soil and explain the reason for erosion difference for different parts. For the soil mechanical properties, numerous research has focused on the influence of the cohesive forces on shear strength characteristics [11-15], and the effect of fines on the mechanical properties [16, 17]. Ouyang et al. [18] concluded that soil shear strength exerted a huge impact on soil erodibility, which thus could be used to determine soil erosion intensity. Helson et al. [19] used soil shear strength to study the mechanism of soil splashing erosion and proved that there was a close relationship between the amount of splash erosion and shear strength. But there was little research on the influence of mechanical parameters on the gully, especially in the special geomorphology of a well-developed gully region. Gully erosion could be divided into different developmental stages according to the visible phenomenon such as the amount of collapsed soil [2-6].

Long-term field surveys found that gullies at different active stages experienced obvious changes with different morphological characteristics of their headcut heights, wall-slope and bed width. Bennett et al. [20] applied fractal geometry theory to explore the gully fractal curvature characteristics. Wuddivira et al. [10] integrated GPS instruments into gully morphology monitoring. At the same time, numerous studies had shown that hypsometric intergral (HI) was a kind of macroscopic topography index with definite physical and geomorphological meaning as one of the quantitative analysis parameters for the stage of geomorphologic development [21-24]. The geomorphic information entropy theory was a method derived from information entropy principle to determine the degree of topographic development [24, 25], which proved to be suitable for the quantitative study regarding the small-scale erosion topography [13]. It could be seen that it was feasible to judge the extent of gully erosion using the geomorphic information entropy theory.

Gullies are formed due to a height drop caused by a terrace or river bank, which develop by way of headward retreat on erodible hillslopes [2-6]. Furthermore, the gully slopes are often more steep upstream (compared to downstream) of gully headcut heights [1]. Studies had shown that gully morphological characteristics were an effective agent for geomorphologic change in gully systems [26-29]. These studies provide important insight into processes and mechanisms of gully landform evolution and erosion. However, research on the relationship between gully activity and morphological characteristics was still rarely reported. Related research mainly focused on the qualitative study on gully evolution lacking quantitative criteria for evaluation factors. In this region, in particular, morphological characteristics of gully erosion have not been well quantified. Since gully activity dominates the development direction of the whole gully system, quantitative study on determining the different gully activities was of great significance to the controlling practice. In this study, therefore, the RTK-GPS instrument and GIS technique were applied to evaluate the activities and morphological characteristics of gully development. The soil shear strength indices for different parts of a gully were measured and the differences of mechanical properties were discussed.

\section{Material and Methods}

\section{Study Area}

Experiments were carried out at the Yuanmou Gully Erosion and Collapse Experimental Station, a field station operated by the Chengdu Institute of Mountain

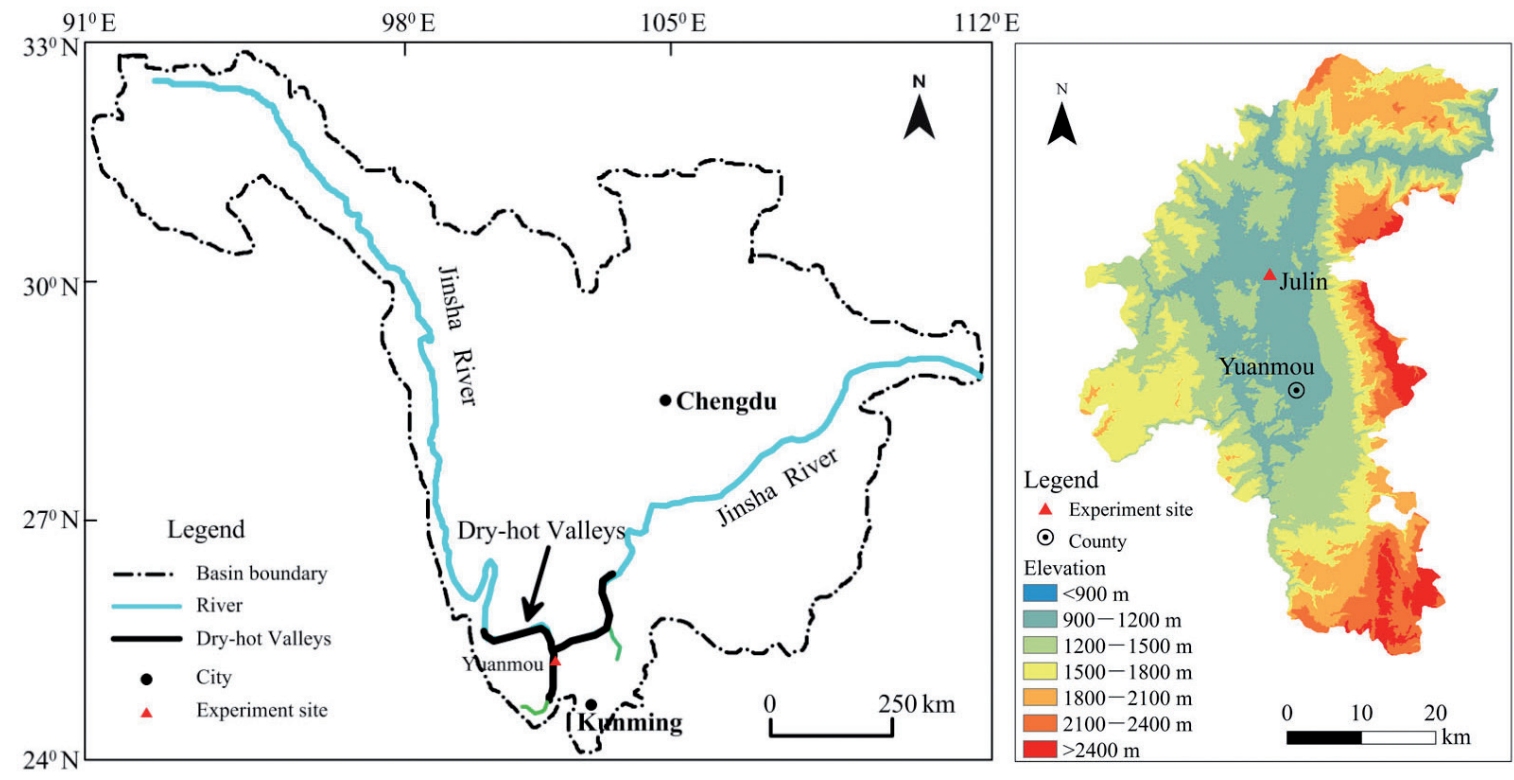

Fig. 1. DEM and location of study site of the Yuanmou Dry-hot Valley region in China. 

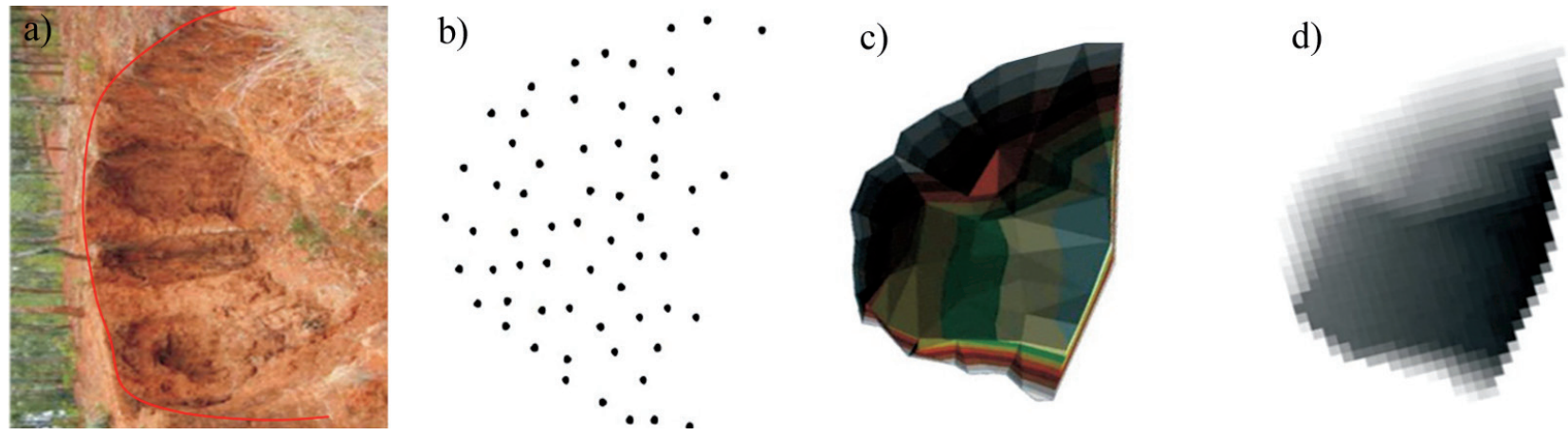

Fig. 2. Processing of gully field measurement data; different lowercase letters (a, b, c, d) refer to field photo, RTK-GPS database, tin model and DEM, respectively.

Hazards and Environment (IMHE), Chinese Academy of Sciences (CAS). The station is situated within Yuanmou County $\left(25^{\circ} 23^{\prime} \mathrm{N}\right.$ to $26^{\circ} 06^{\prime} \mathrm{N}, 101^{\circ} 35^{\prime} \mathrm{E}$ to $\left.102^{\circ} 06^{\prime} \mathrm{E}\right)$, Yunnan Province, China, and is part of the Jinsha River Basin (Fig. 1). The study area is under the influence of a dry-hot climate with a mean annual precipitation of $634.0 \mathrm{~mm}$, a mean annual temperature of $21.8^{\circ} \mathrm{C}$, and an average annual potential evaporation of $3847.8 \mathrm{~mm}$. Rainstorm events typically last from one to two hours and approximately six to seven major high-intensity storms occur in this area each year. Total evaporation is greater than precipitation by 5.8 times, which accounts for the dry-hot climate of the region [25]. The dominant soil type is dry red soil with bulk densities of 1.4 to $1.8 \mathrm{~g} \mathrm{~cm}^{3}$, respectively, classified as Ustic Ferrisols in Chinese Taxonomy and Ferralic Cambisol in the FAO soil taxonomic system [26]. The soil erosion rates were estimated at $1.64 \times 10^{4} \mathrm{t} \mathrm{km}^{-2} \mathrm{a}^{-1}$ in the Yuanmou Dryhot Valley Region [25]. Gully erosion accounts for much of the total soil erosion that takes place, having a gully density between 3 and $5 \mathrm{~km} \mathrm{~km}^{-2}$ [1-4]. Accordingly, this area in the mountainous region of southwestern China is considered an ecologically fragile zone. Moreover, the area is difficult to revegetate due to its extreme climate and serious soil erosion. Zonal vegetation type is tropic bushveld with a scattering of trees. The vegetation of the dry-hot valley region is dominated by herbs belonging to the Heteropogon genus and Bothriochloa pertusa species as well as sparsely dispersed Leucaena leucocephala and Dodonaea viscosa shrub species. It consequently resembles a tropical savanna ecosystem $[1-4]$.

\section{Methods}

\section{Extracting Gully Morphological Data Based on ArcGIS Software}

Thirty-six gullies developed in the dry-hot valley were selected and measured by RTK-GPS instrument( Trimble R8 with $10 \mathrm{~mm} \pm 1 \quad \mathrm{ppm}$ RMS dynamic measurement and $20 \mathrm{~mm} \pm 1 \mathrm{ppm}$ RMS dynamic accuracy, respectively). Using ArcGIS 10.2 software, the measured scattering coordinate data is processed and analyzed to generate a digital elevation model (DEM) with a resolution of $0.1 \times 0.1 \mathrm{~m}$. Using DEM to extract gully morphological parameters (gully width, gully head-cut height, gully wall-slope and other parameters et al.). The specific steps were as follows (Fig. 2): 1) import RTK-GPS database into ArcGIS software as point files, 2) generate tin models using Arc Map's 3D analyst tool, 3) convert tin to a digital elevation model (DEM) with a resolution of $0.1 \mathrm{~m} \times 0.1 \mathrm{~m}$ using the convert tin to grid tool, and 4) extract morphological parameters.

\section{Application of Geomorphic Information Entropy to Judge the Activeness of Gully Development}

Hypsometric intergral $(H I)$ could be expressed as follows:

$$
H I=\left(H_{\text {mean }}-H_{\text {min }}\right) /\left(H_{\text {max }}-H_{\text {min }}\right)
$$

...where $H_{\text {mean }}$ is average elevation, $H_{\text {min }}$ is minimum elevation, and $H_{\max }$ is maximum elevation.

The geomorphic information entropy value could determine the extent of the development of landform erosion and should be calculated as follows:

$$
H=S-1-\ln S=\int_{0}^{1} f(x) d x-1-\ln \left[\int_{0}^{1} f(x) d x\right]
$$

...where $H$ is the geomorphic information entropy value, $S$ is Strahler area-elevation integration value, and $f(x)$ is the Strahler area -elevation fitting function curve.

\section{Direct Shearing Tests}

The soil samples were taken from the gully head, gully wall and gully bed, respectively, in each gully of the selected 36 ones. The surface soil was collected with a $60 \mathrm{~cm}^{3}$ ring cutter (matched with the direct shearing device), the sampling depth was $2 \mathrm{~cm}$, and 4 replications were set for each part. The soil samples were collected with plastic wraps and were sealed immediately. After 
completing the pre-treatments, the shearing tests were carried out on the strain-controlled direct shearing device with vertical loads of $100 \mathrm{k} \mathrm{Pa}, 200 \mathrm{k} \mathrm{Pa}$, $300 \mathrm{k} \mathrm{Pa}$ and $400 \mathrm{k} \mathrm{Pa}$, respectively, and a shear rate of $0.8 \mathrm{~mm} / \mathrm{min}$. Obtained by the vertical stress and shear stress in the coordinate system, the number of points were connected with the line, that was, the destruction of the envelope, while measuring soil friction angle $(\varphi)$ and cohesion (c), and could be expressed as follows:

$$
\tau=\sigma \operatorname{tg} \varphi+c
$$

...where $\tau$ is the soil shear strength, $\mathrm{kPa} ; \sigma$ is the normal stress acting on the shear plane, $\mathrm{k} \mathrm{Pa} ; \varphi$ is soil friction angle $\left({ }^{\circ}\right)$; and $c$ is cohesion, $\mathrm{k} \mathrm{Pa}$.

\section{Data Analysis}

ArcGIS10.2 was used to extract gully morphology data. All statistical analysis were carried out using Origin software (version 8.0).

\section{Results and Discussion}

\section{Morphological Characteristics of Different Activeness Gully}

\section{Gully Classification and Spatial Distribution Trend with Different Activity}

According to the research results of the topography information entropy, the geomorphic erosion could be divided into the following three different stages. When the value of $H<0.1110$, the geomorphologic development stage was the infancy stage; when $0.1110 \leq H \leq 0.4000$, it was the maturity stage; when $H>0.4000$, which was the grontic stage. Based on the above classification criterions, the gullies in the study area belonged to the maturity stage of geomorphic erosion. According to the field investigations for gully development, this paper classified the maternal age entropy $(0.1110 \sim 0.4000)$ into three grades, namely named active period $(0.1110 \leq H \leq 0.1885)$, semiactive period $(0.1886 \leq H \leq 0.2225)$ and stable period $(0.2226 \leq H \leq 0.4000)$. The Significant differences were found in the values of information entropy between the active, semi-active and stable gullies (Table 1).

\section{Morphological Characteristics of Different Gully Activeness}

(1) Gully head-cut height and gully width-depth ratio. Under both gravitational and hydraulic erosion, the headwad erosion led to longer and deeper gullies, and the collapse of soil in the gully wall extended the gully width. The higher the fall height caused by runoff flushing, the more frequent the undercutting and collapse activities occur. And most of the development of cavities, gutter traceable erosion, and vice versa. The average head-cut heights of active gully, semiactive gully and stable gully existed at significant differences, with the values of $1.72 \mathrm{~m}, 0.88 \mathrm{~m}$ and $0.48 \mathrm{~m}$, respectively (Table 2). The width-depth ratios of active gully, semi-active gully and stable gully were $3.24,3.49$ and 4.58, respectively, and showed significant differences as well.

(2) Gully wall-slope. The gully wall-slope was the ratio of vertical height to horizontal width of the gully wall. The wall-slopes in the study area were all greater than $60^{\circ}$. The wall-slopes of the active gully, semiactive gully and stable gully were $89.76^{\circ}, 81.23^{\circ}$ and $60.53^{\circ}$, respectively (Table 2). There was significant difference between the stable gully wall-slope and the rest, and the active gully wall-slope was the largest and nearly vertical. Therefore, the greater the wall-slope, the greater its probability for collapsing, and thus the more actively the gully developed. Active gully and semiactive gully wall-slopes were more prone to collapse, at a stable gully wall almost no collapse occurs, and water erosion on original gully wall continued to slow down. The study found that no significant difference existed between active gully and semi-active gully wallslopes, and should be combined with other indicators of comprehensive discrimination. Being combined with other indicators was needed to make a comprehensive discrimination.

(3) The gully bed-gradient ratio. The gully bedgradient ratio reflected the erosion and siltation balance in a gully bed. The difference of bed-gradient ratio of active, semi-active and stable gully was significant, which was $47.36 \%, 28.93 \%$ and $15.73 \%$, respectively. It could be concluded that the more active the gully

Table 1. Gully activity characteristics based on information entropy.

\begin{tabular}{|c|c|c|c|c|c|}
\hline \multirow{2}{*}{$\begin{array}{c}\text { Information entropy } \\
\text { classification criterions }\end{array}$} & \multirow{2}{*}{ Activity characteristics } & \multicolumn{4}{|c|}{ Statistical Features } \\
\cline { 3 - 6 } & & Relative height $/ \mathrm{m}$ & Area $/ \mathrm{m}^{2}$ & $\mathrm{~S}$ & $\mathrm{H}$ \\
\hline $0.1110 \sim 0.1885$ & Active gully & $3.88 \pm 2.36 \mathrm{a}$ & $58.26 \pm 54.51 \mathrm{a}$ & $0.55 \pm 0.03 \mathrm{a}$ & $0.15 \pm 0.02 \mathrm{c}$ \\
\hline $0.1886 \sim 0.2225$ & Semi-active gully & $3.41 \pm 1.61 \mathrm{a}$ & $42.72 \pm 42.39 \mathrm{~b}$ & $0.49 \pm 0.01 \mathrm{~b}$ & $0.21 \pm 0.01 \mathrm{~b}$ \\
\hline $0.2226 \sim 0.4000$ & Stable gully & $2.84 \pm 1.06 \mathrm{~b}$ & $43.67 \pm 34.58 \mathrm{~b}$ & $0.45 \pm 0.01 \mathrm{c}$ & $0.25 \pm 0.02 \mathrm{a}$ \\
\hline
\end{tabular}

Note: Data in the table indicate the mean value \pm the standard value, $n=12$. Different lowercase letters for the same stage show significant differences among different gullies at the 0.05 level. 
Table 2. Gully morphological parameters.

\begin{tabular}{|c|c|c|c|c|c|c|}
\hline $\begin{array}{c}\text { Activity } \\
\text { characteristics }\end{array}$ & Gully width $/ \mathrm{m}$ & Gully depth $/ \mathrm{m}$ & $\begin{array}{c}\text { Gully head-cut } \\
\text { height } / \mathrm{m}\end{array}$ & $\begin{array}{c}\text { Gully width- } \\
\text { depth ratio }\end{array}$ & $\begin{array}{c}\text { Gully wall-slope } \\
/{ }^{\circ}\end{array}$ & $\begin{array}{c}\text { Gully bed-gradi- } \\
\text { ent ratio }\end{array}$ \\
\hline Active gully & $6.65 \pm 1.03 \mathrm{a}$ & $2.11 \pm 0.54 \mathrm{a}$ & $1.72 \pm 0.36 \mathrm{a}$ & $3.24 \pm 0.36 \mathrm{~b}$ & $89.76 \pm 0.48 \mathrm{a}$ & $47.36 \pm 5.75 \mathrm{a}$ \\
\hline Semi-active gully & $4.11 \pm 0.27 \mathrm{~b}$ & $1.18 \pm 0.11 \mathrm{~b}$ & $0.88 \pm 0.19 \mathrm{~b}$ & $3.49 \pm 0.17 \mathrm{~b}$ & $81.23 \pm 0.65 \mathrm{a}$ & $28.93 \pm 2.76 \mathrm{~b}$ \\
\hline Stable gully & $3.08 \pm 0.42 \mathrm{c}$ & $0.68 \pm 0.11 \mathrm{c}$ & $0.48 \pm 0.1 \mathrm{c}$ & $4.58 \pm 0.26 \mathrm{a}$ & $60.53 \pm 0.99 \mathrm{~b}$ & $15.73 \pm 1.89 \mathrm{c}$ \\
\hline
\end{tabular}

Note: Date in the table indicate the mean value \pm the standard value. Different lowercase letters for the same stage show significant differences among different gullies at the 0.05 level.

development, the greater the bed-gradient ratio, and the gully bed was dominated by runoff erosion. On the contrary, the more stable the gully development, the smaller the bed-gradient ratio, the weaker the water erosion, and the gully bed was dominated by sediment. Field research could verify this conclusion to some extent by the serious erosion occurring in an active gully head due to dropping water from the upstream area drop-falling erosion eroded violently in an active gully head, and in a stable gully due to long-term sedimentation, the gully bed topography tended to be flat.

\section{Mechanical Properties of Gullies with Different Gully Activeness}

\section{Soil Shear Strength of Gullies with Different Activeness}

The soil particles and aggregates were arranged in a certain form of soil structure. The frictional forces of different particles and the occlusal forces generated by the intercalation and interlocking of particles affect their ability to resist the destruction of external forces. The soil shear strength in different parts of gullies were plotted in the form of Mohr stress circle (Fig. 3). The shear strength of active gully head under 4 confining pressure showed the largest, and the active gully bed was the smallest. This might be the development of a large number of ferromanganese film in active gully head. The shear strength of semi-active gully was the smallest under the 4 confining pressures. When the pressure was less than $200 \mathrm{kPa}$, the shearing strength of the gully wall was greater than that of the gully bed. After the confining pressure increases to $200 \mathrm{kPa}$, the shearing strength of the gully bed was the highest. Field survey found that the semi-active gully head exist head ward erosion and vegetation had growth on a semi-active gully bed. When the confining pressure was less than $400 \mathrm{kpa}$, the shearing strength of the stable gully wall was smaller than that of the stable gully head. When the confining pressure exceeds $400 \mathrm{kpa}$, the shearing strength of the stable gully wall was larger than that of the stable gully head. This indicates that the information entropy of stable gully reaches 0.25 , soil erosion was relatively light, and almost no collapse occurs in the stable gully wall. Especially the stable gully bed had undergone many years of physical weathering, surface and subsurface biological functions, soil particle structure was good, and mechanical properties were stable.

\section{The Internal Friction Angle of Gully Various Parts}

There was a significant linear positive correlation between soil friction angle and soil moisture content in gullies $(P<0.05)$ (Table 3$)$. The greater the ability of soil particles to resist runoff scouring damage with more stable soil mechanical properties, which were hard to be destroyed by water flow. Among them, regression analysis on the frictional angle and moisture content of a gully with different activity showed that the internal frictional angle of gully wall and soil moisture content showed a significant linear positive correlation $(P<0.05)$. This indicated that different moisture content a)

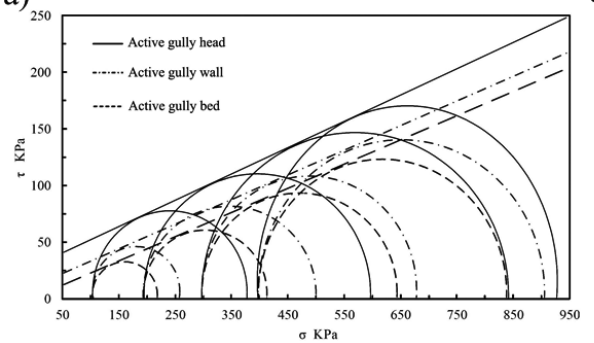

b)

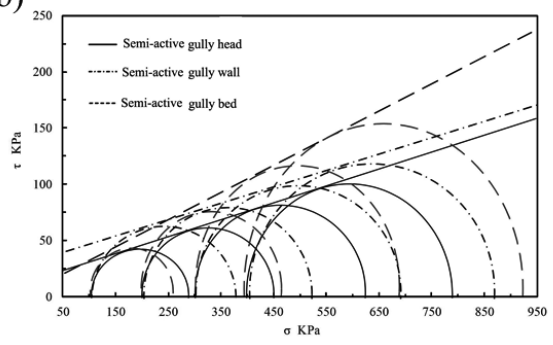

c)

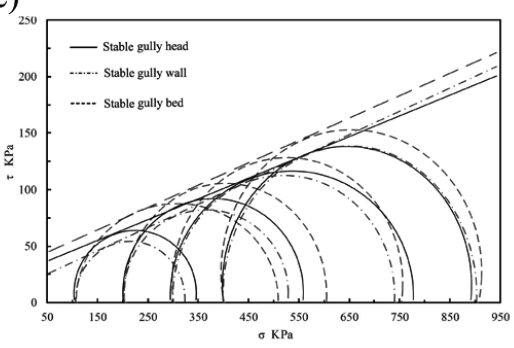

Fig. 3. The shear strength of different parts of the gullies; different lowercase letters (a, b, c) refer to active gully, semi-active gully and stable gully, respectively. 
Table 3. Regression analysis on the frictional angle and moisture content of a gully with different activeness.

\begin{tabular}{|c|c|c|c|c|c|}
\hline Gully various parts & Gullies with different activity & Regression equation & $R^{2}$ & $F$ & $P$ \\
\hline \multirow{3}{*}{ Gully head } & Stable gully & $y=26.715 x-0.105$ & 0.901 & 27.127 & $0.014^{*}$ \\
\cline { 2 - 6 } & Semi-active gully & $y=25.822 x-0.179$ & 0.891 & 25.839 & $0.015^{*}$ \\
\cline { 2 - 6 } & Active gully & $y=31.238 x-0.224$ & 0.899 & 26.811 & $0.014^{*}$ \\
\hline \multirow{3}{*}{ Gully wall } & Stable gully & $y=22.516 x-0.122$ & 0.989 & 264.48 & $0.001^{* *}$ \\
\cline { 2 - 6 } & Semi-active gully & $y=23.752 x-0.187$ & 0.944 & 50.691 & $0.006^{* *}$ \\
\cline { 2 - 6 } & Active gully & $y=19.715 x-0.105$ & 0.938 & 45.331 & $0.007^{* *}$ \\
\hline \multirow{3}{*}{ Gully bed } & Stable gully & $y=30.141 x-0.074$ & 0.862 & 18.805 & $0.023^{*}$ \\
\cline { 2 - 6 } & Semi-active gully & $y=38.019 x-0.096$ & 0.869 & 19.91 & $0.021^{*}$ \\
\cline { 2 - 6 } & Active gully & $y=38.335 x-0.159$ & 0.889 & 24.101 & $0.016^{*}$ \\
\hline
\end{tabular}

Note: $R^{2}, F$ and $P$ refer to determination, significance test and significance. $*$ and $* *$ indicate the relationship reaches 0.05 and 0.01 significant level, respectively.

had a great influence on the internal friction angle. The fitting between friction angle and soil moisture content in the gully bed was the smallest $\left(R^{2}<0.9\right)$.

\section{The Soil Cohesion in Various Parts of a Gully}

Although the moisture content increased as the experiment progressed, soil cohesion showed a powerfunction decline trend $(\mathrm{P} \leq 0.01)$ in gully various part and different active gullies (Table 4). It could be seen that cohesion $\mathrm{c}$ decreased with the increase of soil moisture content, and there showed a significant linear negative correlation $\left(R^{2}>0.92, \quad P<0.01\right)$. Regression analysis showed that the soil moisture content had a great influence on the soil cohesion in a gully. These results also indicate that soil cohesion was much lower in a stable gully than in the active gully.

Soil mechanical properties and morphological characteristics behave differently under the gully systems. Calculating topographic information entropy showed that the different developmental periods of gully erosion could be determined as active period, semi- active period and active stage, according to different topographic information entropy $(0.1110 \leq H \leq 0.1885$, $0.1886 \leq H \leq 0.2225,0.2226 \leq H \leq 0.4000$ ) (Fig. 4).

The present study has confirmed that the $H$ values of active gully, semi-active gully and stable gully were $0.15,0.21$ and 0.25 , respectively. Based on the information entropy classification, the morphological characteristics of gully (gully width, average gully depth, width-depth ratio, bed-gradient ratio, gully wallslop, and head-cut height) were significantly different. However, it should be noted that gully morphological development was controlled by many factors, such as climate, topography, geotechnical properties, etc., and soil consisted of soil particles, aggregates, soil pores and organic matter, etc. Previous studies had shown that soil characteristics can have a significant impact on the gully erosion process [1, 33]. Moreover, the gully morphological characteristics would be significantly affected by the weathering and soil cracking processes as a result of direct long-term exposure to sunlight [1]. Accordingly, the soil shear strength would also be affected by such processes [33]. It may be worth noting that the soils were largely free

Table 4. Regression analysis on soil cohesion and moisture content of a gully with different activeness.

\begin{tabular}{|c|c|c|c|c|c|}
\hline Gully various parts & Different active gullies & Regression equation & $R^{2}$ & $F$ & $P$ \\
\hline \multirow{3}{*}{ Gully head } & Stable gully & $y=101.046 x-0.084$ & 0.965 & 82.843 & $0.003^{* *}$ \\
\cline { 2 - 6 } & Semi-active gully & $y=75.96 x-0.184$ & 0.931 & 40.458 & $0.008^{* *}$ \\
\cline { 2 - 6 } & Active gully & $y=57.528 x-0.216$ & 0.927 & 38.117 & $0.009^{* *}$ \\
\hline \multirow{3}{*}{ Gully wall } & Stable gully & $y=108.131 x-0.122$ & 0.969 & 92.294 & $0.002^{* *}$ \\
\cline { 2 - 6 } & Semi-active gully & $y=85.553 x-0.146$ & 0.965 & 83.621 & $0.003^{* *}$ \\
\cline { 2 - 6 } & Active gully & $y=81.813 x-0.205$ & 0.956 & 65.311 & $0.004^{* *}$ \\
\hline \multirow{3}{*}{ Gully bed } & Stable gully & $y=88.157 x-0.081$ & 0.968 & 91.559 & $0.002^{* *}$ \\
\cline { 2 - 6 } & Semi-active gully & $y=72.564 x-0.141$ & 0.955 & 63.198 & $0.004^{* *}$ \\
\cline { 2 - 6 } & Active gully & $y=53.872 x-0.205$ & 0.932 & 41.246 & $0.008^{* *}$ \\
\hline
\end{tabular}

Note: $R^{2}, F$ and $P$ refer to determination, significance test and significance. $*$ and $* *$ indicate the relationship reaches 0.05 and 0.01 significant level, respectively. 
a)

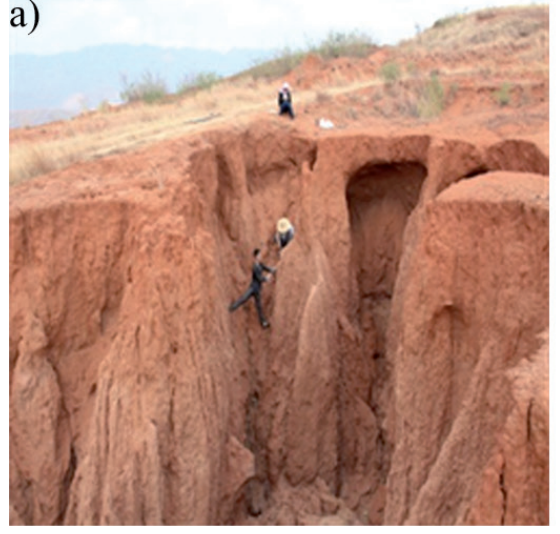

b)

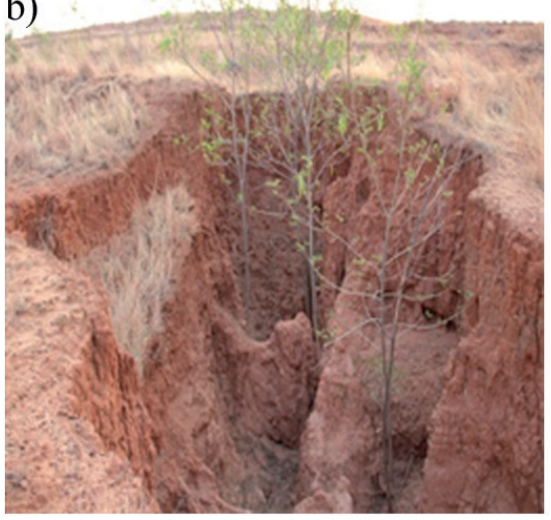

c)

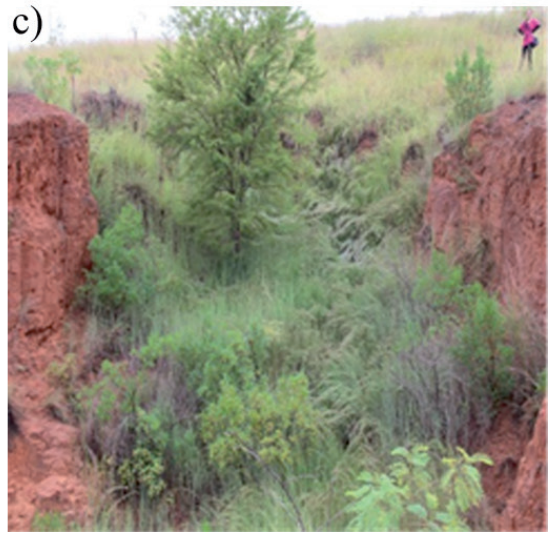

Fig. 4. Photos of the gullies with different morphological characteristics; different lowercase letters (a, b, c) refer to active, the semiactive and the stable gullies, respectively.

of stones, as this may affect the soil shear strength processes of various gully parts and different gully activeness.

Field study found that the soil in active gully head was unstable, collapsing frequently and the soil erosion occurred seriously. In conclusion, the morphological characteristics of different active gully (gully width, average gully depth, width-depth ratio, bed-gradient ratio, gully wall-slop, head-cut height) were significantly different. The soil shear strength under different parts of gullies varied with different gully activeness, and the different soil moisture contents significantly affected the internal friction angle and cohesion index of gullies. In the Dry-Hot Valley region the development of steep headcuts is perceived to be a significant morphological feature of an active gully [3], especially the development of plunge pools at the feet of the headcuts, and several studies have focused on gully headward erosion in this region [30]. Gully morphological development was controlled by many factors, such as climate, topography, geotechnical properties, etc., and the soil consisted of the soil particles, aggregates, soil pores and organic matter, etc. [1-7]. The soil shear strengths under different parts of a gully were varied, and the different soil moisture contents significantly affect the internal friction angle and cohesion index of a gully [15]. In addition to gully development by the influence of water force, uplift force and effective gravity, differences of soil mechanical properties also play a role. The soil with lower cohesion under water erosion was easily loose before causing erosion $[1,5]$. Both the soil internal friction angle and soil cohesion were more sensitive to changes in moisture content at low levels than high ones. That could indicate that the effects of soil moisture had a great contribution to gully soils in the Dry-Hot Valley in which the wet and dry seasons were apparently distinct. Studies reported that this result could be ascribed to vertical variation in soil mechanical properties. It should be noted that a significant correlation was found between soil moisture content and soil shear strength [33]. Accordingly, more attention should be paid to vertical variations in soil mechanical properties and weathering processes.

This might be due to the largest gully headcut height value with undercutting and collapsing activities occurring most frequently [30-33]. In a semiactive gully, the gully head-cut height value was lower than that of an inactive gully, but its gully wall-slope was very steep and more prone to collapse, and thus affected soil stability. The stable gully with the smallest gully bed-gradient ratio was dominated by sediment deposition, and its gully bed terrain tended to be gentle. A field survey found that the growth of gully vegetation with different active degrees of gully in the Dry-Hot Valley were different, and the vertical soil of the gully could be divided into 4 sections with 28 layers. The active gully extremely developed and all parts of that had almost no vegetation growth. The stable gully was barely eroded, and all parts of that almost had vegetation growth. In this paper, the dynamic characteristics of gullies with different active degrees were not analyzed comparatively, and the relevant discussions could be strengthened in the future.

Under the erosion of water flow, the anti-erosion ability of the lower sandy layer was obviously weaker than that of the upper clayey layer, causing it to be washed away first, resulting in the hanging state of the upper clayey layer and creating a collapse potential for the gully head and gully wall. A field study found that soil in an active gully head was unstable, collapsing frequently and soil erosion occured seriously. Although it would be interesting to assess its morphological characteristics for different gully sections and time periods, the significant advances in the understanding of gully erosion in this region are well worth celebrating; nevertheless, we still do not understand the mechanisms, especially the evolutionary mechanisms for different gully activity. Therefore, further quantitative studies are required to quantify spatial and temporal relationships between morphological characteristics and mechanical properties for different soil types, soil layers and geomorphic locations in the Dry-Hot Valley region. 


\section{Conclusions}

This research was conducted to determine a gully's morphological characteristics and its soil mechanical properties in the Dry-Hot Valley region. The results prove that the different developmental periods of gully erosion could be identified as active period, semiactive period and active stage according to different topographic information entropy. Besides, the soil shear strength under different parts of a gully vary with different active degrees of gully. Additionally, the different soil moisture contents significantly affect the internal friction angle and cohesion index of a gully. Furthermore, the gully morphology indicators that affected the gully soil mechanical properties were found to be gully head drop-height, gully wall-slope and bed-gradient ratio. The significant advances in the understanding of gully erosion in this region are well worth celebrating. In particular, the findings of the present study suggest that gully erosion with different topographic information entropy results in different morphological characteristics, and that gully erosion contributes to soil mechanical properties.

\section{Acknowledgements}

This work was supported by the National Natural Science Foundation of China (No. 41571277), the Strategic Priority Research Program of the Chinese Academy of Sciences (XDA20020401), and the National Basic Research Programme (973 Programme) of China (2015CB452704). The authors are also grateful for comments from Professor Hanna Radecka and Professor Jerzy Radecki, as well as the reviewers.

\section{Conflict of Interest}

The authors declare no conflict of interest.

\section{References}

1. CHEN A., ZHANG D., YAN B., LEI B., LIU G. Main types of soil mass failure and characteristics of their impact factors in the Yuanmou Valley, China. Catena. 125, 82, 2015.

2. YANG D., XIONG D., GUO M., SU Z., ZHANG B., ZHENG X., FANG H. Impact of grass belt position on the hydraulic properties of runoff in gully beds in the Yuanmou Dry-hot valley region of Southwest China. Physical Geography. 36 (5), 408, 2015.

3. DONG Y.,WU Y.,ZHANG T., YANG W., LIU B. The sediment delivery ratio in a small catchment in the black soil region of Northeast China. International Journal of Sediment Research.28,111,2013.

4. ZHU P., WANG Z. W., QIN Z. W., SHEN Y. The transfer path analysis method on the use of artificial excitation: Numerical and experimental studies. Applied Acoustics 136, 102, 2018
5. SU Z.A., XIONG D. H., DONG, Y. F., Li J. J., YANG D., ZHANG J., HE G. Simulated head-ward erosion of bank gullies in the Dry-hot Valley Region of southwest China. Geomorphology. 204, 532, 2014.

6. ZHANG D., CHEN A.Q., WANG X., LIU G. Quantitative determination of the effect of temperature on mudstone decay during wet-dry cycles: A case study of 'purple mudstone' from south-western China. Geomorphology. 246, 1, 2015.

7. GOU S., WANG Y., YIN J., WU Y., DONG Y. Investigation of Soil Shear-Strength Parameters and Prediction of the Collapse of Gully Walls in the Black Soil Region of Northeastern China. Physical Geography. 32 (2), 161, 2011.

8. TANG L. S., CONG L., GENG X. L., GAN F. The effect of freeze-thaw cycling on the mechanical properties of expansive soils. Cold Regions Science and Technology. 145, 197, 2018.

9. COMINO E., DRUETTA A. The effect of Poaceae roots on the shear strength of soils in the Italian alpine environment. Soil and Tillage Research. 106 (2), 194, 2010.

10. WUDDIVIRA M. N., STONE R. J., EKWUE E. I. Influence of cohesive and disruptive forces on strength and erodibility of tropical soils. Soil and Tillage Research. 133, 40, 2013.

11. XIAO H., LIU G., ZHANG Q., FEN L. Z., ZHANG X., LIU P., ZHANG J. Quantifying contributions of slaking and mechanical breakdown of soil aggregates to splash erosion for different soils from the Loess plateau of China. Soil and Tillage Research. 178, 150,2018.

12. SUNIL B. M., SHRIHARI S., NAYAK S. Shear strength characteristics and chemical characteristics of leachatecontaminated lateritic soil. Engineering Geology. 106 (1), 20, 2009.

13. ZHANG T., CAI G., LIU S. Assessment of mechanical properties in recycled lignin-stabilized silty soil as base fill material. Journal of Cleaner Production. 172, 1788, 2018.

14. YIN D.S., LI H.W., DUAN X.M. Fractional description of mechanical property evolution of soft soils during creep. Water Science and Engineering. 6 (4), 446, 2013.

15. TAGAR A.A., CHANG Y.J., QI S.D., ADAMOWSKI J., MALARD J., ELTOUM F.A. Implications of variability in soil structures and physio-mechanical properties of soil after different failure patterns. Geoderma. 261, 124, 2016.

16. ZHAO Y., GAO Y., ZHANG Y., WANG Y. Effect of fines on the mechanical properties of composite soil stabilizerstabilized gravel soil. Construction and Building Materials. 126, 701, 2016.

17. PASCULLI A., SCIARRA N., ESPOSITO L., ESPOSITO A. W. Effects of wetting and drying cycles on mechanical properties of pyroclastic soils. Catena. 156, 113, 2017.

18. OUYANG W., WU Y., HAO Z., ZHANG Q., BU Q., GAO X. Combined impacts of land use and soil property changes on soil erosion in a mollisol area under longterm agricultural development. Science of The Total Environment. 613, 2018.

19. HELSON O., BEAUCOUR A. L., ESLAMI J., NOUMOWE A., GOTTELAND P. Physical and mechanical properties of soilcrete mixtures: Soil clay content and formulation parameters. Construction and Building Materials. 131, 775, 2017.

20. BENNETT S.J., CASALI J., ROBINSON K.M., KADAVY K.C. Characteristics of actively eroding ephemeral gullies in an experimental channel. Transactions of the ASAE. 43 (3), 641, 2000. 
21. WALCOTT R.C., SUMMERFIELD M.A. Scale dependence of hypsometric integrals: An analysis of southeast African basins. Geomorphology. 96 (1), 174, 2008

22. BANNISTER E.N. Hypsometries of Michigan's Southeastern Lake Plain. Journal of Great Lakes Research. 6 (2), 154, 1980.

23. SU Z.A., XIONG D.H., DONG Y.F., ZHANG B.J., ZHANG S., ZHENG X.Y., FANG H.D. Hydraulic properties of concentrated flow of a bank gully in the dry-hot valley region of southwest China. Earth Surface Processes and Landforms, 40 (10), 1351, 2015.

24. HARTE J., NEWMAN E.A. Maximum information entropy: a foundation for ecological theory. Trends in Ecology \& Evolution. 29 (7), 384, 2014.

25. ZHONG X.H. Degradation of ecosystem and ways of its rehabilitation and reconstruction in dry and hot valley. Resources and Environment in the Yangtze Basin. 9 (3), 336, 2000.

26. FAO. Soil Map of the World (revised legend), World Soil Resources Report 60. FAO: Rome. 1988.

27. ZHU P., WANG Z., QIN Z., SHEN Y. The transfer path analysis method on the use of artificial excitation: Numerical and experimental studies. Applied Acoustics. 136, 102, 2018.

28. SAHANAVIN N., PRUEKSASIT T., TANTRAKARNAPA $\mathrm{K}$. Relationship between $\mathrm{PM}_{10}$ and $\mathrm{PM}_{2.5}$ levels in high- traffic area determined using path analysis and linear regression. Journal of Environmental Sciences. 69, 105, 2018.

29. HITCHMAN S.M., MATHER M.E., SMITH J.M., FENCL J.S. Habitat mosaics and path analysis can improve biological conservation of aquatic biodiversity in ecosystems with low-head dams. Science of The Total Environment. 619, 2018.

30. CHEN A.Q., ZHANG D., PENG H., FAN J.R., XIONG D.H., LIU G.C. Experimental study on the development of collapse of overhanging layers of gully in Yuanmou Valley, China. Catena. 109, 177, 2013.

31. BROOKS A.P., SHELLBERG J.G, KNIGHT J., SPENCER J. Alluvial gully erosion: an example from the Mitchell fluvial megafan, Queensland, Australia. Earth Surface Processes and Landforms. 34 (14), 1951, 2009.

32. ABRAMS D.M., LOBKOVSKY A.E., PETROFF A.P., STRAUB K.M., MCELROY B., MOHRIG D.C., KUDROLLI A., ROTHMAN D.H. Growth laws for channel networks incised by groundwater flow. Nature Geoscience. 2 (3), 193, 2009.

33. SU Z.A., XIONG D.H., DONG Y.F., YANG D., ZHANG S., ZHANG B.J., SHI L.T. Influence of bare soil and cultivated land use types upstream of a bank gully on soil erosion rates and energy consumption for different gully erosion zones in the dry-hot valley region, Southwest China. Natural Hazards. 79 (S1), 183, 2015. 